\title{
Quality of Life in the Perspectives of Teachers in COVID 19 Pandemic Era: Implications for Funding Allocation for Faculty Well-being Initiatives
}

\author{
RUSSELL D'SOUZA \\ NIRMALA INSTITUTE OF EDUCATION, Goa, INDIA. E-mail: russsouza@gmail.com
}

\begin{abstract}
People all around the globe have been impacted by the COVID-19 global health crisis, which has led to severe mental and psychological health problems and a weakened overall sense of well-being. However, there is not a lot of information available regarding the effect of COVID-19 on Indian instructors. The objective of this research was to discover if COVID-19 impacts the professional teachers' quality of life (QoL) in India. The descriptive study that included 890 licensed teachers was the respondents of this cross-sectional approach. The primary instrument in this research was the COVID-19 Impact on Quality of Life (COV19-QoL). Statistics used to evaluate the data included descriptive statistics, t-test, and one-way ANOVA to measure the effect of COVID-19 on the QoL of instructors. Results showed that it had a modest impact. COVID-19 impacted QoL differently depending on the program degree. The effect of COVID-19 on the patient's overall quality of life did not vary greatly according to age, sex, marital status, employment status, monthly salary, whether or not they had any COVID19-related cases near their home, whether or not they knew anyone who had contracted or died from COVID19 , and whether or not they believed they were at risk. Teachers' mental health and quality of life must also be attended to, and supports must be offered to enable them to cope with the ramifications of the COVID-19 pandemic. This research has added to the increasing body of literature on the pandemic's effect, making it an important source of data for future investigations.
\end{abstract}

Keywords: COVID 19; Mental Health; Teachers; Quality of Life.

JEL Classification: I20, M10, I10

Received: June 09, 2021

Accepted: October 01, 2021 


\title{
La Calidad de Vida en la Perspectiva de los Profesores en la era de la Pandemia COVID 19: Implicaciones de la Asignación de Fondos para las Iniciativas de Bienestar del Profesorado
}

\author{
RUSSELL D'SOUZA \\ NIRMALA INSTITUTE OF EDUCATION, Goa, INDIA. E-mail: russsouza@gmail.com
}

\begin{abstract}
RESUMEN
Personas de todo el mundo se han visto afectadas por la crisis sanitaria mundial del COVID-19, que ha provocado graves problemas de salud mental y psicológica y un debilitamiento de la sensación general de bienestar. Sin embargo, no hay mucha información disponible sobre el efecto del COVID-19 en los instructores indios. EI objetivo de esta investigación era descubrir si la COVID-19 influye en la calidad de vida (QoL) de los profesores profesionales en la India. El estudio descriptivo que incluyó a 890 profesores licenciados fue el que respondió a este enfoque transversal. El instrumento principal de esta investigación fue el COVID-19 Impact on Quality of Life (COV19-QoL). Las estadísticas utilizadas para evaluar los datos incluyeron la estadística descriptiva, la prueba t y el ANOVA de una vía para medir el efecto de la COVID-19 en la calidad de vida de los instructores. Los resultados mostraron que tuvo un impacto modesto. La COVID-19 tuvo un impacto diferente en la calidad de vida según el grado del programa. El efecto de la COVID-19 en la calidad de vida general del paciente no varió mucho en función de la edad, el sexo, el estado civil, la situación laboral, el salario mensual, si tenían o no algún caso relacionado con la COVID-19 cerca de su casa, si conocían o no a alguien que hubiera contraído o fallecido a causa de la COVID-19 y si creían o no estar en riesgo. También hay que atender la salud mental y la calidad de vida de los profesores, y ofrecerles apoyos para que puedan hacer frente a las ramificaciones de la pandemia de COVID-19. Esta investigación se ha sumado al creciente cuerpo de literatura sobre el efecto de la pandemia, lo que la convierte en una importante fuente de datos para futuras investigaciones.
\end{abstract}

Palabras clave: COVID 19; Salud mental; Profesores; Calidad de vida.

Clasificación JEL: 120, M10, 110

Recibido: 09 de Junio de 2021

Aceptado: 01 de Octubre de 2021 


\section{Introduction}

A worldwide health disaster, with unparalleled problems in education, has arisen from the COVID19 public health crisis. It has been discovered that COVID-19, the causative agent of the dengue virus, has infected 308,000 people in India. The rising number of instances of COVID-19 is despite the concerted efforts of the government to curtail the spread of the disease. Countries across the world are trying to be ready for the virus' future challenges, such as health, economics, and education (Vu et al., 2020, Macintyre et al., 2020, Sokal et al., 2020).

On the other side, as school seclusion and the world become more interconnected, teachers may suffer an increase in worry. The dangerous situation teachers find themselves in includes both their personal and professional lives. The risk of COVID-19 exposure to teachers and their families is somewhat outweighed by the additional demands they encounter in transitioning to the new educational environment. Teaching using the new method doesn't need having up-to-date resources, technology, and expertise.

More recently, SARS, MERS-CoV, H1N1, and Ebola outbreaks have been identified, as well as the link between mental health and the effects on others (Jogezai et al., 2021). This research is now being conducted in order to uncover the information on COVID-19 and find out about the potential effects of a COVID-19 pandemic on mental health and QoL. This study of the effects of the COVID-19 pandemic on mental health and quality of life for the general Indian population and the health and well-being of adults who were not infected with COVID-19 after two months of quarantine also evaluated the mental health and quality of life of the population and of adults who were not infected with COVID-19. The researcher wanted to understand more about how COVID-19 affects the quality of life in breast and ovarian cancer and sarcomas patients. It is essential to learn how this occurs since COVID-19 may have a negative effect on the people of poorly affected countries, such as India.

During the global health crisis, the working style of teachers has changed significantly. Before the pandemic, these professions had been extensively researched, and the results indicated a high level of job stress that contributed to burnout (Liu, et al, 2021, Maclntyre, Gregersen, \& Mercer, 2020, Poelmann, et al, 2021). According to certain studies, instructors may be stressed out due to dire working circumstances, problems with pupils or families, or organizational issues (Sani, et al, 2021, Sokal, Trudel, \& Babb, 2020, Sveinsdóttir, et al, 2021, Taylor, Thomas-Gregory, \& Hofmeyer, 2020). Teaching is a full-time job that requires instructors to manage their time and allocate additional hours for caring for children and their guardians, creating lesson plans, and planning, all of which teachers do primarily at home. Teachers have also reported various pandemic issues, such as the high incidence of chronic non-transmissible illnesses linked to declining quality of life (QoL). High obesity rates and poor physical activity levels are common problems (associated with post-work fatigue and late work hours). Increased incidence of musculoskeletal diseases, burnout syndrome, sadness, and anxiety Due to the large percentage of women in this field, these issues are compounded even more among females. Age is also a significant concern since it is linked to higher mental and physical decline. Work overload, teleworking, and other issues contribute to decreased physical and psychological quality of life. The study's goal was to see how instructors fared regarding health-related QoL before and during the COVID-19 pandemic.

We haven't seen a worldwide pandemic similar to the modern world rise since the rise of the modern world. Nevertheless, previous pandemics and economic crises may offer important learning opportunities (UNESCO, 2020a). The current pandemic's effect on people's mental and physical health may be inferred from previous experience. Although mental and emotional difficulties may be avoided and quality of life enhanced by regular physical exercise, being physically active should be highly recommended as a preventative measure against the COVID-19 pandemic (Maqsood et al., 2021). While under lockdown, teachers should take care of their personal well-being, just as they do outside of lockdown. Increased physical activity may both help with your overall health and reduce your risk of developing illnesses and disorders. People who spend more time being physically active during free 
time or in a more autonomous manner may reduce their risk of getting illnesses and disorders (Kapasia et al., 2020).

A major part of planning for the future is understanding the impact each element has on the lockdown scenario since this helps us guide the group toward an after-crisis setting and reduces the possible repercussions in future crisis circumstances. According to researchers, teachers can be found in the scientific literature with periods of upheaval and unrest due to large numbers of job dissatisfaction, stress, burnout, and depression, all caused by large bureaucratic structures, demanding workloads, and diminished motivation. Issues of indiscipline, instability and professional insecurity are also linked to these issues (Ahorro, et al, 2021, Charernnit, et al, 2021, De Souza, et al, 2021, Lopez, et al, 2021, Magulod Jr, 2017, Magulod Jr, 2019, Magulod, et al, 2021, Magulod, et al, 2020, Nuncio, et al, 2020).

We are constantly in a state of change when it comes to societal institutions, political systems, and the population's well-being. Teachers have recently been dealing with a number of continuing changes to their teaching frameworks due to the COVID-19 pandemic (Ziauddeen et al., 2020, Xiang, Zhang, \& Kuwahara, 2020, Baron et al., 2020).

As the highly transmissible virus spread throughout the globe, countries raced to plan for the resulting health, economic, and educational difficulties. COVID-19 cases continue to rise in India despite strong government efforts to halt the disease's spread (Bordoloi \& Das, 2021, Jena, 2020, Khan, et al, 2021). Teachers may experience unexpected anxiety due to school closings and social isolation being imposed across the world (Kumar, Singh, \& Parkash, 2021). It's an uncertain time for teachers, both professionally and personally (Mathur, 2021). Along with physical health concerns, COVID-19 poses substantial threats and dangers to mental health and well-being due to elevated levels of worry and stress, which are compounded by the situation's ongoing ambiguity. The psychological effect of COVID-19 is no exception. In addition, apart from the possible pressures that instructors experience due to the danger of COVID-19 to themselves and their families, they are compelled to adjust to the new standard in the educational environment and to conduct effective remedial instruction (Patra, Sundaray, \& Mahapatra, 2021, Rafi, Varghese, \& Kuttichira, 2020). Teachers may not be equipped with the latest technology, resources, and skills needed to participate in and thrive in this new teaching style.

This study examined many factors in order to find the forces that affect teachers' well-being in the midst of a pandemic while also serving as helpful tools for teachers in terms of their job satisfaction and outlook for the future. There is a dearth of quality-of-life literature among the Indian people, particularly among professionals. This research was done to assess the effect of COVID-19 on the QoL of licensed professional teachers in India, which is mainly linked to their mental health. This will be a basis for providing funds in initiating mental health development program in the University.

\section{Methodology}

The design used in this study is a descriptive, cross-sectional study. 890 Indian teachers were the participants in this research. The study was performed among qualified professional Faculty from three States, namely, Goa, Maharashtra, and Karnataka, who were employed in government-aided and private colleges. The primary instrument in this research was the COVID-19 Impact on Quality of Life (COV19-QoL), which was used to capture the impact of COVID-19 on the following areas: mental health. During the last seven days, participants rated their emotions and thoughts for each answer using a five-point Likert scale that ranged from 1 (totally disagree) to 5 (absolutely agree).

The six-item Perceived Coronavirus Threat Questionnaire (PCTQ) was used to assess COVID-19 threat-related thoughts and concerns. All participants were guaranteed to have a chance to be involved in the study. Descriptive statistics, an independent sample t-test, and one-way Analysis of Variance (ANOVA) were used to evaluate the data with the help of the Statistical Package for Social Sciences (SPSS) version 23.0 after a normality test was completed on the dependent variable. A p-value of .05 was selected for this experiment, which means that the results are statistically significant. 
The internal consistency of Cronbach's alpha was good (Alpha Cronbach $=.80$ on the tool). This study used Cronbach's $\alpha=.90$. Researchers also ascertained the participants' demographic characteristics, such as age, gender, race, and socioeconomic status, as well as their knowledge of someone who is infected with COVID-19 or who dies from COVID-19, as well as whether the participants were aware of any medical conditions that increase their chances of developing a severe case of COVID-19 disease. The respondents were asked to respond to the following question on a fivepoint Likert scale, with 1 meaning "it's completely untrue of me" and 5 meaning "it's totally true of me" (very true of me). According to Cronbach's $\alpha$ recorded in the PCTQ, it was about .87. The internal consistency of the current research was found to be $\alpha=.75$. The proposal was approved by the head of the graduate program's administration. The research participants were made aware of the objective of the experiment. While participants were still recounting their responses, researchers ensured the privacy of all information by telling them that giving consent to be questioned allows participants to be surveyed.

\section{Results and Discussion}

\subsection{Profile Characteristics}

Table 1 shows the profile characteristics of the respondents. The majority of them are 31-40 years old $(49 \%)$, female $(57 \%)$, married $(57 \%)$, have finished Master's Degree $(87 \%)$, and regular Faculty (56\%). Most of them earn a monthly salary of one to two lakhs (35\%). Most of them have admitted that there is an emergence of COVID 19 cases in their near residence (100\%), have knowledge on the persons who died to COVID (100\%). This study looked into the impact of COVID-19 on the QoL of teachers. This study found that the mean composite score of teachers in the COV19-QoL scale was 2.75 , nearly six months since India implemented strict community quarantine across the archipelago.

Table 1 Profile Characteristics of the Respondents

\begin{tabular}{|c|c|c|c|}
\hline Profiles & Categories & $\begin{array}{c}\text { Frequency } \\
(\mathrm{n}=890)\end{array}$ & Percentage \\
\hline \multirow{3}{*}{ Age } & 30 and below & 300 & 34 \\
\hline & $31-40$ years old & 440 & 49 \\
\hline & 41 and above & 150 & 17 \\
\hline \multirow{2}{*}{ Sex } & Male & 387 & 43 \\
\hline & Female & 503 & 57 \\
\hline \multirow{2}{*}{ Marital Status } & Single & 380 & 43 \\
\hline & Married & 510 & 57 \\
\hline \multirow{2}{*}{ Highest Education } & Doctoral & 120 & 13 \\
\hline & Masters & 770 & 87 \\
\hline \multirow{2}{*}{ Employment } & Regular & 500 & 56 \\
\hline & Contractual/Other & 390 & 44 \\
\hline \multirow{4}{*}{ Monthly Salary } & Above 2 lakhs & 168 & 19 \\
\hline & 1.0 to 2.0 lakhs & 312 & 35 \\
\hline & 075 to 1.0 lakh & 290 & 33 \\
\hline & Less than 0.75 lakh & 120 & 13 \\
\hline \multirow{2}{*}{ Emergence of COVID Cases near the home } & Yes & 770 & 87 \\
\hline & No & 120 & 13 \\
\hline \multirow{2}{*}{$\begin{array}{l}\text { Have knowledge on the number of people } \\
\text { infected of COVID } 19 \text { in the area }\end{array}$} & Yes & 890 & 100 \\
\hline & No & 0 & 0 \\
\hline \multirow{2}{*}{$\begin{array}{l}\text { Have knowledge on the persons who die due to } \\
\text { COVID } 19 \text { in the area }\end{array}$} & Yes & 890 & 100 \\
\hline & No & 300 & 34 \\
\hline
\end{tabular}




\subsection{Presence of Medical Conditions of the Sampled Teachers}

Table 2 shows the presence of medical conditions among the sampled teachers. The majority of them have medication conditions (61\%). When taken individually, the dominant is hypertension (22\%), followed by Asthma (17\%), diabetes (11\%), obesity (10\%), and surgeries (1\%). In like manner, there were 350 respondents from 890 or $39 \%$ do does not have medical conditions. The finding shows that majority of the teachers have comorbidities.

Table 2 Presence of Medical Conditions

\begin{tabular}{|c|c|c|}
\hline Categories & $\begin{array}{c}\text { Frequency } \\
(\mathbf{n = 8 9 0 )}\end{array}$ & Percentage \\
\hline Yes & 540 & 61 \\
\hline Hypertension & 200 & 22 \\
\hline Asthma & 150 & 17 \\
\hline Diabetes & 95 & 11 \\
\hline Obesity & 91 & 10 \\
\hline Surgeries & 4 & 1 \\
\hline No & 350 & 39 \\
\hline & & \\
\hline
\end{tabular}

\subsection{Perceived Threat of COVID 19}

Table 3 presents the perceived threat of COVID 19 Pandemic by the teachers. It can be surmised from the table that the majority of the respondents highly perceived COVID 19 as a threat (61\%), $28 \%$ of them perceived it as a moderate threat, while the least of $11 \%$ of them perceived it as a low threat.

Table 3 Perceived Threat of COVID 19

\begin{tabular}{|c|c|c|}
\hline Perceived Threat & $\begin{array}{c}\text { Frequency } \\
(\mathbf{n}=\mathbf{8 9 0})\end{array}$ & Percentage \\
\hline High Threat & 540 & 61 \\
\hline Moderate Threat & 250 & 28 \\
\hline Low Threat & 100 & 11 \\
\hline
\end{tabular}

\subsection{Perceived Impact of COVID 19 on the Quality of Life of the Teachers}

The quality of life of European patients (with serious mental disorders) was shown to be higher in those people who were impacted by the COVID-19 pandemic $(M=2.40)$. Also, in patients with cancer, patients' emotional and social functioning was impaired. COVID-19 was found to have a little impact on the quality of life for residents but only a small impact on their well-being (Pu \& Zhong, 2020, Chen et al., 2020). Teachers who were most affected by the pandemic were concerned about their personal safety, which was then followed by an overall decline in quality of life. In a study done by Repiski and colleagues, it was found that the quality of life (QoL) was significantly affected by the crisis in the COVID-19, but mental health was hardly affected (Zhou \& Li, 2020, Wang \& Zhao, 2020). COVID-19 seems to represent a serious and present threat to the safety and well-being of persons, and this leads to an increase in people's emphasis on their physical well-being.

Instructors said that they were glad the nation was isolated so they could spend more time with their families. Students will have developed coping mechanisms to deal with the demands of the pandemic that the teachers may have acquired as a result of the earlier phases of the lockdown. As long as the disease breakout is still a concern, it is not expected to be as much of a threat as it was while the population was under quarantine for the first several weeks when very little was known about the pandemic. 
Table 3 Perceived Threat of COVID 19

\begin{tabular}{|c|c|c|c|}
\hline Perceived Threat of COVID 19 & Mean & SD & Rank \\
\hline $\begin{array}{l}\text { I feel that my personal safety is at } \\
\text { risk }\end{array}$ & 3.60 & 1.09 & 1 \\
\hline $\begin{array}{l}\text { I think my quality of life is lower } \\
\text { than before }\end{array}$ & 3.04 & 1.08 & 2 \\
\hline I feel tenser than before & 2.76 & 1.13 & 3 \\
\hline $\begin{array}{l}\text { I think my physical health may } \\
\text { deteriorate }\end{array}$ & 2.41 & 1.31 & 4 \\
\hline I feel more depressed than before. & 2.37 & 1.15 & 5 \\
\hline $\begin{array}{l}\text { I think my mental health has } \\
\text { deteriorated }\end{array}$ & 2.08 & 0.92 & 6 \\
\hline Cov19-QoL (total scale) & 2.75 & & \\
\hline
\end{tabular}

\subsection{Test of Comparison and Differences in the Impact of COVID 19}

The quality of life of European patients (with serious mental disorders) was shown to be higher in those people who were impacted by the COVID-19 pandemic $(M=2.40)$. Also, in patients with cancer, patients' emotional and social functioning was impaired. COVID-19 was found to have a little impact on the quality of life for residents in Liaoning Province, mainland China, but only a small impact on their well-being. Teachers who were most affected by the pandemic were concerned about their personal safety, which was then followed by an overall decline in quality of life. In a study done by Repiski and colleagues, it was found that the quality of life (QoL) was significantly affected by the crisis in the COVID-19, but mental health was hardly affected. COVID-19 seems to represent a serious and present threat to the safety and well-being of persons, and this leads to an increase in people's emphasis on their physical well-being. Filipino instructors said that they were glad the nation was isolated so they could spend more time with their families. Students will have developed coping mechanisms to deal with the demands of the pandemic that the teachers may have acquired as a result of the earlier phases of the lockdown. As long as the disease breakout is still a concern, it is not expected to be as much of a threat as it was while the population was under quarantine for the first several weeks when very little was known about the pandemic.

Table 4 Test of Differences

\begin{tabular}{|c|c|}
\hline Variables & P- value \\
\hline Age & $.841 \mathrm{~ns}$ \\
\hline Sex & $.088 \mathrm{~ns}$ \\
\hline Marital Status & $.438 \mathrm{~ns}$ \\
\hline Degrees Attained & $.011^{*}$ \\
\hline Employment Status & $.760 \mathrm{~ns}$ \\
\hline Monthly Salary & $.877 \mathrm{~ns}$ \\
\hline Presence of COVID-19 case near residence & $.688 \mathrm{~ns}$ \\
\hline Personally know infected of COVID-19 & $.473 \mathrm{~ns}$ \\
\hline
\end{tabular}

${ }^{*}=$ significant at 0.05 level; $n s=$ not significant at 0.05 level

Note: all other variables are not significant

In this part, you can see that the usage of COVID-19 in a degree program influences mental health. Nonetheless, mental health impacts were no differences based on the types of variables listed above, with the exception of employment status and proximity to a virus reservoir. While people's feelings of threat or safety may have an influence on their quality of life, the results of this study indicate no significant difference in the impact of COVID-19 on QoL regardless of whether individuals are aware of COVID-19's presence or not. Indians are widely known for their natural talent for getting through tough situations and challenges in their daily lives. Additionally, a study shows that Indians' strong religious and family ties, their sense of humor, their hope, their optimism, their inventiveness, and their adaptability serve as protective traits. While the study found that people's personal experience with the virus and others, they know telling them about the virus had a significant impact on their risk 
estimate, the data did not support the theory. Additionally, the presence of COVID-19 fostered an intensified feeling of danger, which was connected to feelings of depression, wrath, anxiety, and despair-hostility. COVID-19 risk was described as moderate to high in this study. Even though they were not helpless, almost half of the participants in a study done in China reported emotions of terror and panic at the outbreak of the pandemic. Even in the event of a global pandemic, not paying attention to the concerns of students, teachers, and policymakers while transitioning to different remote, distant, flexible, hybrid, or online learning methods cannot be excused.

In this context, the Ministry of Education, Government of India, respective State Directorates of Higher Education and Universities encouraged the use of flexible, blended, modular, or online teaching methods in place of conventional methods so as to avoid interpersonal contact and delivered education using computer networks rather than face-to-face interaction.

\section{Conclusion}

Teachers are greatly impacted by the COVID-19 pandemic. While the moderate to high danger of COVID-19 did factor into teacher quality of life six months after the lockdown, the teachers seem to have somehow dealt with the effect of COVID-19 as shown by the moderate level influence on their quality of life in regard to mental health. Regardless, instructors should also take care of their physical and emotional well-being. Teachers also need assistance in adjusting to the effect that the COVID-19 pandemic has had on them. As an implication of this study for funding allocation for faculty well-being initiatives, the hard lesson that has involved alleviating the difficult situation of the pandemic disease leads to three action points: the establishment of measures to facilitate the online teaching resources; the design of teaching strategies that favor teaching-learning processes based on blended or online methods; and the development of support programs to foster physical activity among citizens. In the final analysis, for the prevention of future health issues for teachers, it is critical that families take steps to increase the amount of physical activity their children engage in at home. Thus, teachers who want to use blended or online learning should have their skills trained in mixed or online teaching techniques. It is made apparent in this exercise that keeping an eye on the continued existence of (professionally) happy instructors is very important and a must in order to keep this field's study current. This research has the potential to stir up individuals, helping them mobilize both with respect to teaching methods and teacher effectiveness. Also emphasized and underscored is how important it is to research the different kinds of well-being, as outlined in COVID-19, so that governments may better assist people in developing and implementing educational programs and reforms. We are optimistic that our research may make a positive difference in improving teachers' well-being at a time when their profession is now plagued by a pandemic. These are measures that fall not only on political leaders or teachers and school leaders but also on families themselves. This shows that, like the fight against COVID-19, this is a shared responsibility.

\section{Limitation and Future Research Directions}

This research's main limitation is that it does not provide a holistic regional and global perspective. Additional influences on mental health should be accounted for in addition to those related to the job and personal situations during the lockdown. Therefore, further research is required to ascertain if these results are accurate. Additionally, we must also examine whether instructors have the relevant skills and expertise required to make use of the various resources. The teachers said that they might need to get training in teaching and learning methods since the concepts they demonstrate in the classroom are different from those needed on the internet. Even with the complicated situation, more detailed training for teachers is still required. The transition from the classroom to the Internet proved to be difficult for many. 
1. Ahorro, A. M. T., David, M. R. T., Molina, J. M. V., Pangilinan, A. B. Y., \& Arcinas, M. M. (2021). Correlations between the Senior High School Grade 12 Students' Perception of School Classroom Climate and Compliance to School Classroom Norms in a Private University in Manila, Philippines. International Journal of Multidisciplinary: Applied Business and Education Research, 2(4), 274-284.

2. Arcinas, M. M. (2021). A Blockchain Based Framework For Securing Students Educational Data. LINGUISTICA ANTVERPIENSIA, 4475-4484.

3. Baron, E. J., Goldstein, E. G., \& Wallace, C. T. (2020). Suffering in silence: How COVID-19 school closures inhibit the reporting of child maltreatment. Journal of public economics, 190, 104258.

4. Bordoloi, R., Das, P., \& Das, K. (2021). Perception towards online/blended learning at the time of Covid-19 pandemic: an academic analytic in the Indian context. Asian Association of Open Universities Journal.

5. Charernnit, K., Alhourani, A. Q., Arcinas, M. M., Velasco, L. G., \& Alhourani, A. Q. Cognitive and Attitudinal Effects of Jigsaw Technique as a Collaborative Learning Strategy in Literature Teaching in the Philipines.

6. Chen, T., Peng, L., Jing, B., Wu, C., Yang, J., \& Cong, G. (2020). The impact of the COVID-19 pandemic on user experience with online education platforms in China. Sustainability, 12(18), 7329.

7. De Souza, R., Parveen, R., Chupradit, S., Velasco, L. G., Arcinas, M., Tabuena, A. C., ... \& Ventayen, R. J. M. (2021). Language Teachers' Pedagogical Orientations in Integrating Technology in the Online Classroom: Its Effect on Students Motivation and Engagement. Turkish Journal of Computer and Mathematics Education, 12.

8. Jena, P. K. (2020). Online learning during lockdown period for covid-19 in India. International Journal of Multidisciplinary Educational Research (IJMER), 9.

9. Jogezai, N. A., Baloch, F. A., Jaffar, M., Shah, T., Khilji, G. K., \& Bashir, S. (2021). Teachers' attitudes towards social media (SM) use in online learning amid the COVID-19 pandemic: the effects of SM use by teachers and religious scholars during physical distancing. Heliyon, 7(4), e06781.

10.Kapasia, N., Paul, P., Roy, A., Saha, J., Zaveri, A., Mallick, R., ... \& Chouhan, P. (2020). Impact of lockdown on learning status of undergraduate and postgraduate students during COVID-19 pandemic in West Bengal, India. Children and Youth Services Review, 116, 105194.

11.Khan, M. A., Nabi, M. K., Khojah, M., \& Tahir, M. (2021). Students' perception towards e-learning during COVID-19 pandemic in India: An empirical study. Sustainability, 13(1), 57.

12.Kumar, D., Singh, D., \& Parkash, P. (2021). Psychological Well-Being and Quality of Worklife of the School Teachers during the Covid-19 Situation. European Journal of Molecular \& Clinical Medicine, 7(7), 6309-6316.

13.Liu, J., Wang, W., Hu, Q., Wang, P., Lei, L., \& Jiang, S. (2021). The relationship between phubbing and the depression of primary and secondary school teachers: A moderated mediation model of rumination and job burnout. Journal of Affective Disorders.

14.Lopez, K. R. B., Gaticales, N. P., Provido, A. V. C., Santelices, S. M. B., \& Arcinas, M. M. (2021). Social Contagion of Astrology in the Social Media amid COVID-19 Pandemic. International Journal of Multidisciplinary: Applied Business and Education Research, 2(4), 349-363.

15.MacIntyre, P. D., Gregersen, T., \& Mercer, S. (2020). Language teachers' coping strategies during the Covid-19 conversion to online teaching: Correlations with stress, wellbeing and negative emotions. System, 94, 102352.

16. Magulod Jr, G. C. (2017). Factors of school effectiveness and performance of selected public and private elementary schools: implications on educational planning in the Philippines. Asia Pacific Journal of Multidisciplinary Research, 5(1), 73-83.

17. Magulod Jr, G. C. (2019). Learning styles, study habits and academic performance of Filipino University students in applied science courses: Implications for instruction. JOTSE: Journal of Technology and Science Education, 9(2), 184-198. 
18. Magulod, G. C., Capulso, L. B., Dasig, J. P., Baluyot, M. B. B., Nisperos, J. N. S., Reyes-Chua, E., \& Chupradit, S. (2021). Attainment of the Immediate Program Graduate Attributes and Learning Outcomes of Teacher Candidates towards Global Competence Initiatives. International Journal of Learning, Teaching and Educational Research, 19(12).

19.Magulod, G. C., Capulso, L. B., Tabiolo, C. D. L., Luza, M. N., \& Ramada, M. G. C. (2020). Use of technology-based tools in ensuring quality of publishable journal articles. Int J Learn Teach Educ Res, 19, 145-162.

20.Maqsood, A., Abbas, J., Rehman, G., \& Mubeen, R. (2021). The paradigm shift for educational system continuance in the advent of COVID-19 pandemic: Mental health challenges and reflections. Current Research in Behavioral Sciences, 2, 100011.

21. Mathur, A. (2021). The Challenges and Glitches Faced by Teachers of Central India during Lockdown and Solutions. Turkish Journal of Computer and Mathematics Education (TURCOMAT), 12(12), 144151.

22.Nuncio, R. V., Arcinas, M. M., Lucas, R. I. G., Alontaga, J. V. Q., Neri, S. G. T., \& Carpena, J. M. (2020). An E-learning outreach program for public schools: Findings and lessons learned based on a pilot program in Makati City and Cabuyao City, Laguna, Philippines. Evaluation and Program Planning, $82,101846$.

23.Patra, S. K., Sundaray, B. K., \& Mahapatra, D. M. (2021). Are university teachers ready to use and adopt e-learning system? An empirical substantiation during COVID-19 pandemic. Quality Assurance in Education.

24.Poelmann, F. B., Koëter, T., Steinkamp, P. J., Vriens, M. R., Verhoeven, B., \& Kruijff, S. (2021). The immediate impact of the coronavirus disease 2019 (COVID-19) pandemic on burn-out, workengagement, and surgical training in the Netherlands. Surgery.

25.Pu, M., \& Zhong, Y. (2020). Rising concerns over agricultural production as COVID-19 spreads: Lessons from China. Global food security, 26, 100409.

26.Rafi, A. M., Varghese, P. R., \& Kuttichira, P. (2020). Concerns and confidences expressed by teaching staff about the shift of medical education to online mode in South India during the COVID 19 pandemic. Journal of Ideas in Health, 3(Special2), 272-275.

27.Sani, I., Hamza, Y., Chedid, Y., Amalendran, J., \& Hamza, N. (2020). Understanding the consequence of COVID-19 on undergraduate medical education: Medical students' perspective. Annals of medicine and surgery, 58, 117-119.

28.Sokal, L., Trudel, L. E., \& Babb, J. (2020). Canadian teachers' attitudes toward change, efficacy, and burnout during the COVID-19 pandemic. International Journal of Educational Research Open, 1, 100016.

29.Sokal, L., Trudel, L. E., \& Babb, J. (2020). Canadian teachers' attitudes toward change, efficacy, and burnout during the COVID-19 pandemic. International Journal of Educational Research Open, 1, 100016.

30.Sveinsdóttir, H., Flygenring, B. G., Svavarsdóttir, M. H., Thorsteinsson, H. S., Kristófersson, G. K., Bernharđsdóttir, J., \& Svavarsdóttir, E. K. (2021). Predictors of university nursing students burnout at the time of the COVID-19 pandemic: A cross-sectional study. Nurse Education Today, 106, 105070.

31.Taylor, R., Thomas-Gregory, A., \& Hofmeyer, A. (2020). Teaching empathy and resilience to undergraduate nursing students: A call to action in the context of Covid-19. Nurse education today, 94, 104524.

32.Vu, C. T., Hoang, A. D., Than, V. Q., Nguyen, M. T., Dinh, V. H., Le, Q. A. T., ... \& Nguyen, Y. C. (2020). Dataset of Vietnamese teachers' perspectives and perceived support during the COVID-19 pandemic. Data in brief, 31, 105788.

33.Wang, C., \& Zhao, H. (2020). The impact of COVID-19 on anxiety in Chinese university students. Frontiers in psychology, 11, 1168.

34.Xiang, M., Zhang, Z., \& Kuwahara, K. (2020). Impact of COVID-19 pandemic on children and adolescents' lifestyle behavior larger than expected. Progress in cardiovascular diseases, 63(4), 531. 
35.Zhou, L., \& Li, F. (2020). A review of the largest online teaching in china for elementary and middle school students during the COVID-19 pandemic. Best Evid Chin Edu, 5(1), 549-567.

36.Ziauddeen, N., Woods-Townsend, K., Saxena, S., Gilbert, R., \& Alwan, N. A. (2020). Schools and COVID-19: Reopening Pandora's box?. Public Health in Practice, 1, 100039. 